\title{
Alternative approach to mastitis management - How to prevent and control mastitis without antibiotics?
}

\author{
Abordagem alternativa para o manejo da mastite - Como prevenir e controlar a mastite sem \\ antibióticos?
}

Sofie PIEPERS ${ }^{1,2}$; Sarne DE VLIEGHER ${ }^{1,2}$
${ }^{1}$ Ghent University, Faculty of Veterinary Medicine, Department of Reproduction, Obstetrics, and Herd Health, M-team and Mastitis and Milk Quality Research Unit - Merelbeke, Belgium
${ }^{2}$ MEXCELLENCE BVBA, MEX ${ }^{\mathrm{nx}}$ - Merelbeke, Belgium

\begin{abstract}
Mastitis affects a high proportion of dairy cows throughout the world and is one of the greater problems faced by the dairy industry today. The disease is still a major cause of economic loss on a dairy farm. Mastitis poses not only negative consequences for the dairy farmer but also for the dairy industry as a number of issues threaten the reputation of milk as a healthy product from healthy animals. The use of antimicrobials is one of those concerns and threats. Antimicrobial usage on dairy farms is most often related to udder health as most medicines are used in prevention and control of mastitis. Antimicrobials remain vital for treatment of bacterial infections in dairy cattle, but in light of the upcoming debate instigated by the potential link between the use of antimicrobial products in animal husbandry and the development of antimicrobial resistance in both animal and human pathogens, there is an urgent need for innovation and alternatives to antibiotic therapy for mastitis treatment and control. Alternative approaches include vaccination, probiotics or beneficial microorganisms and inhibitory substances, immunomodulation, bacteriophages, homeopathy, and plant-derived inhibitory substances, yet only when scientifically-proven evidence is available indicating these alternatives are effective.
\end{abstract}

Keywords: Alternative. Mastitis. Treatment. Vaccination.

\section{Resumo}

A mastite ocorre em uma alta proporção de vacas leiteiras em todo o mundo e é um dos grandes problemas que atinge a indústria leiteira. A doença ainda é uma das maiores causas de perdas econômicas das granjas leiteiras. A mastite não tem apenas consequências negativas para os fazendeiros, mas atinge também a indústria leiteira, particularmente pela expectativa de que o leite deve ser um produto saudável produzido por animais saudáveis. O uso de antimicrobianos é uma grande preocupação. O emprego de antimicrobianos nas granjas leiteiras está frequentemente relacionado com a saúde do úbere uma vez que a maioria dos medicamentos são usados na prevenção e controle da mastite. Os antimicrobianos ainda são vitais para o tratamento das infecções bacterianas do gado leiteiro, mas na atualidade há um grande questionamento para a ligação potencial entre o uso de produtos antimicrobianos no manejo animal e o desenvolvimento de resistência antimicrobiana tanto de patógenos de animais como de humanos, há portanto a necessidade urgente da introdução de alternativas para o tratamento e controle da mastite com antibióticos. As possibilidades incluem vacinação, probióticos ou microorganismos benéficos e substâncias inibidoras, imunomodulação, bacteriófagos, homeopatia, fitoterápicos inibidores. Contudo todos esses procedimentos necessitam ser cientificamente provadas para demonstrar que são alternativas realmente efetivos.

Palavras-chave: Alternativas. Mastite. Tratamento. Vacinação. 
Correspondence to:

Sofie Piepers

Ghent University, Faculty of Veterinary Medicine,

Department of Reproduction, Obstetrics, and Herd Health,

M-team and Mastitis and Milk Quality Research Unit

Salisburylaan 13

9820, Merelbeke, Belgium

e-mail: Sofie.Piepers@UGent.be

Received: $17 / 08 / 2017$

Approved: 07/08/2018

\section{Introduction}

Mastitis affects a high proportion of dairy cows throughout the world and is one of the greater problems faced by the dairy industry today (BRADLEY, 2002). The disease is still a major cause of economic loss on any dairy farm. The main financial losses are due to the expense of antibiotic treatment, along with the associated costs of decreased milk production and decreased fertility or, in cases where antibiotic treatment is ineffective or unwanted, culling or death (HALASA et al., 2007). Additionally, farmers supplying milk with a high bulk milk somatic cell count may be losing out on bonus payments and may also incur penalties. Treating infected cows also increases labor (e.g. time and effort) for the farmer and causes stress, consequences that should not be underestimated as both are perceived as the two most annoying aspects of mastitis by farmers (JANSEN et al., 2009).

Mastitis has consequences beyond the dairy farm as well as a number of issues related to the disease that threaten the positive reputation of milk as a healthy, high-quality and nutritious product produced by healthy and contented animals. First, udder health accounts for the largest proportion of antimicrobial drug use on a dairy farm (STEVENS et al., 2016). Second, herds struggling with udder health problems have a higher risk of delivering milk containing antibiotic residues because of their increased (and often injudicious) antibiotic usage (RUEGG; TABONE, 2000). Third, cows suffering from even mild cases of clinical mastitis are in pain, which obviously has its implications for animal welfare. In fact, because of worries about potential antimicrobial residues in milk, emerging antimicrobial resistance, issues with milk quality and animal welfare, mastitis has become a valid concern to consumers and society, a development everyone involved in the dairy industry should be aware of.

Ongoing political debate and public concerns about the emergence of antimicrobial resistance and drug residues in milk emphasize the need for innovation and alternatives to antibiotic therapy. The focus of this manuscript is to describe and discuss mastitis vaccines and alternatives that can potentially be used in the prevention and control of bovine mastitis with a focus on the potential relevance of medium-chain fatty acids (MCFA).

\section{Vaccines}

\section{What is vaccination?}

The immune response of the mammary gland consists of an innate and adaptive immune response arm. The adaptive immune response arm specifically responds to a specific antigen. The innate immune system recognizes conserved microbial molecules via their receptors (RAINARD; RIOLLET, 2006). Besides the macrophages, neutrophils, dendritic cells, and natural killer cells, it also includes physical barriers such as the teat sphincter, and chemical barriers such as the keratin of the teat canal and lactoferrin (SCHUKKEN et al., 2011). Interestingly, milk in healthy cows has a resident population of immune cells. The population is usually dominated by macrophages but also contains neutrophils and lymphocytes (SORDILLO, 2005). Lymphocytes are divided in two groups: T- and B-lymphocytes. The Tlymphocytes are further categorized into $\alpha \beta$ Tlymphocytes, including $\mathrm{CD} 4^{+} \mathrm{T}$-helper lymphocytes and $\mathrm{CD}^{+}$T-cytotoxic lymphocytes, and $\gamma \delta \mathrm{T}$ lymphocytes. In the lactating mammary gland, $\alpha \beta \mathrm{T}$ lymphocytes dominate and primarily express the $\mathrm{CD} 8^{+}$ phenotype (SHAFER-WEAVER; SORDILLO, 1996). Those activated cytotoxic CD8 ${ }^{+} \mathrm{T}$-lymphocytes kill are 
assumed to kill host cells infected with a pathogen, as detected by antigens expressed on the surface of the infected cells. On the contrary, helper $\mathrm{CD}^{+} \mathrm{T}$ lymphocytes have a more indirect but equally important effect on the invaded mastitis-causing pathogens. A CD4 ${ }^{+} \mathrm{T}$-helper lymphocyte that matures usually develops into one of four types of T-helper cells. Stimulation of the latter mature T-helper cells results in the expression of a large variety of cytokines that can direct the immune response towards a B-cellmediated (Th2 response), a pro-inflammatory cytotoxic T-cell-mediated response (Th1 response) or a neutrophil-mediated response (Th17 response) or in the expression of cytokines that counter-regulate the response (Treg response). It is well-known that when bacteria invade the mammary gland and cause an intramammary infection, large numbers of leukocytes migrate into the udder, resulting in the establishment of a host response against the pathogen. Although the increasing body of research that focuses on the immunological response of the mammary gland, the specific leukocyte populations mediating this immune response are currently not yet well defined.

Perhaps the most important consequence of an adaptive immune response is the establishment of a state of immunological memory. Immunological memory is the ability of the immune system to respond more rapidly and effectively to pathogens that have been previously encountered, which happens in case of vaccination (JANEWAY et al., 2001). A distinguishing feature of immunological memory is the irreversible genetic change of B-lymphocytes from IgM producers to producers of other antibody isotypes, including IgG1 and IgG2 (BURTON et al., 2001). In several species including the bovine, an immune response with a higher production of IgG2 antibody has been recognized as part of a Th1 pro-inflammatory response, while a response with a higher production of IgG1 is part of a Th2 or anti-inflammatory response. Because IgG2 is an important opsonizing antibody aiding in neutrophil phagocytosis of bacteria, and IgG2 has the ability to readily fix complement, it has been suggested that an IgG2 Th1-type response might be beneficial against bovine mastitis (THOMPSONCRISPIE et al., 2013).

Each vaccine contains a killed or weakened form of the specific organism (e.g. Staphylococcus aureus, Escherichia coli, ...) that causes a disease such as mastitis. Even though the organism in the vaccine has been altered so that it will not cause sickness, the part of the organism that stimulates the immune system to respond to ("antigen") is still present. Mastitis vaccines against $E$. coli primarily contain the inactive J5 E. coli strain, resulting in the formation of antibodies against the uniform component lipopolysaccharide (LPS) in the outer membrane of all Gram-negative bacteria causing the severe symptoms associated with hyperacute E. coli mastitis cases. Mastitis vaccines against $S$. aureus consist of either bacterins (= killed or avirulent/weakened $S$. aureus strains) or exopolysaccharides (= sugar residues secreted by bacteria in the surrounding environment). One of those exopolysaccharides is poly- $\mathrm{N}$-acetylglucosamine (PNAG), a surface polymer produced by a variety of bacterial species, including $S$. aureus and Staphylococcus epidermidis, and facilitating bacterial cell-to-cell contact in biofilms (PÉREZ et al., 2009).

\section{What is vaccine efficacy?}

Efficacy of a vaccine refers to the reduction in disease measured in a carefully monitored, randomized controlled clinical trial conducted in a homogeneous population according to a defined protocol. In essence, the vaccine efficacy is determined by four parameters. The first parameter is the impact of vaccinations on the rate of new infections. This represents the classic vaccine effect, whereby the vaccine reduces the susceptibility of non-infected individuals such that no or fewer new infections take place. The second parameter is the impact of vaccination on the infectiousness of an infected individual. The vaccine may reduce the amount of shedding of infected but vaccinated individuals compared to nonvaccinated infectious individuals. For 
example, considering $S$. aureus is a mammary pathogen that may be transmitted cow-to-cow, a reduction in the infectiousness of a vaccinated individual would be valuable. The third parameter is the impact of vaccination on the cure of existing infections. Vaccinations may result in a shorter duration of infection. The duration is essentially the inverse of cure, so a higher cure will result in a shorter duration. The fourth and final parameter of vaccine efficacy is the reduction in progression of infection from subclinical to clinical mastitis. As clinical mastitis results in milk discard, treatment and animal sickness, a reduction in progression of infection would be of value to the dairy industry.

\section{Vaccines against mastitis}

Commercial mastitis vaccines are currently available for immunization against mastitis caused by S. aureus and E. coli. In the U.S., there are two S. aureus bacterins available. The vaccines are marketed as Somato-Staph $^{\circledast}$ and Lysigin ${ }^{\circledast}$ and are labeled as somatic antigen containing phage types I, II, III, IV and miscellaneous groups of $S$. aureus. There are also three coliform mastitis vaccines available. Two are identical and marketed as J-5 Bacterin (Hygieia Biological Laboratories, Woodland, California, USA), ENVIRACOR J-5 (Zoetis, Parsippany, New Jersey, US). A separate bacterin-toxoid (J-Vac ${ }^{\oplus}$, Merial Inc., Duluth, Georgia, USA) is also available. The 4th Gramnegative mastitis vaccine contains re-17 mutant Salmonella typhimurium bacterin toxoid. On the European market, there is only one labeled vaccine against mastitis available (Startvac ${ }^{\oplus}$, Hipra S.A., Girona, Spain). The vaccine contains inactivated E. coli (J5), inactivated S. aureus (CP8) SP 140 strain expressing Slime Associated Antigenic Complex (SAAC) and adjuvant. The vaccine has a label claim for reducing the incidence of subclinical mastitis and incidence and severity of clinical signs of clinical mastitis caused by coliform, S. aureus, and non-aureus staphylococci (NAS).
At this time, there are no commercial vaccines available that have a proven efficacy against streptococcal mastitis. Still, the increased frequency of mastitis caused by environmental streptococci such as Streptococcus uberis has resulted in a number of unsuccessful attempts to produce vaccines against this pathogen. The wide strain variety together with the strain-specific protection in particular slows the development of vaccines specifically oriented against mastitis-causing streptococci (DENIS et al., 2009).

\section{Vaccine efficacy}

\section{Vaccine efficacy against S. aureus}

A number of studies have been published on the efficacy of vaccination against $S$. aureus mastitis. In one of the first field trials including 30 heifers, a 3-fold decreased risk of $S$. aureus infections was observed in heifers vaccinated with an experimental vaccine formulation based on inactivated $S$. aureus cells and exopolysaccharides at $5 \mathrm{w}$ and $1 \mathrm{w}$ before calving. Still, no effects on the somatic cell count were found (GIRAUDO et al., 1997). Nickerson et al. (1999) vaccinated heifers with the commercially available Lysigin ${ }^{\circledR}$ (Boehringer Ingelheim Vetmedica Inc., St. Joseph, Missouri, USA) at six months of age followed by a booster dose two weeks later and subsequent vaccinations every six months until calving. Vaccinated heifers had a $45 \%$ reduction in both new $S$. aureus intramammary infections during pregnancy and new $S$. aureus intramammary infections at calving relative to controls. Middleton et al. (2006) compared the efficacy of the same commercially available vaccine with two experimental formulations and nonvaccinated controls in primiparous heifers as well. Heifers were vaccinated twice, 28 days apart in late gestation with either a 3-isolate experimental bacterin (Group I; $\mathrm{n}=11$ ), a 5 -isolate experimental bacterin (Group II; $\mathrm{n}=11$ ), or the commercially available Lysigin (Boehringer Ingelheim Vetmedica Inc., St. Joseph, Missouri, USA) (Group III; $\mathrm{n}=14$ ). Group IV consisted of 11 nonvaccinated control animals. All 
groups (vaccinated animals and nonvaccinated ones) were challenged with a heterologous strain of $S$. aureus by intramammary infusion on days 6-8 of lactation in a single infection-free mammary quarter. All animals became infected with $S$. aureus after challenge. In contrast to the results obtained by Nickerson et al. (1999), no differences in S. aureus clearance rates were observed between groups. Animals vaccinated with Lysigin ${ }^{\circledR}$ (Boehringer Ingelheim Vetmedica Inc., St. Joseph, Missouri, USA) had a lower mean duration of clinical mastitis and showed less severe symptoms than nonvaccinated control animals. There was no evidence that any of the vaccinated groups had a lower somatic cell count than nonvaccinated control animals, and no evidence that vaccinates had a greater milk yield than controls post-challenge. Still, significantly higher concentrations of milk antibodies against $S$. aureus were observed in the Lysigin ${ }^{\circledR}$ (Boehringer Ingelheim Vetmedica Inc., St. Joseph, Missouri, USA) vaccinated animals than in the nonvaccinated control animals (LUBY et al., 2007). Similar results were obtained in studies that used avirulent (PELLIGRINO et al., 2008) or inactivated $S$. aureus (TENHAGEN et al., 2001) vaccine formulations or vaccines including insoluble bacterial fragments of two field S. aureus field strains and secreted antigens of a third field strain (LEITNER et al., 2013). In the latter study, however, the milk somatic cell count was almost $50 \%$ lower in vaccinated animals compared to nonvaccinated animals. Also, the average daily milk yield was $0.5 \mathrm{~kg} /$ day higher in vaccinated animals than in nonvaccinated control cows.

In a recently published study (SCHUKKEN et al., 2014), the efficacy of the novel commercially available vaccine Startvac ${ }^{\circledast}$ (Hipra S.A., Girona, Spain) was evaluated on two commercial dairy farms. In total, 1,156 lactations from 809 cows were enrolled. During the first phase of the trial, all cows that were due to calve were vaccinated until approximately $50 \%$ of the cows in the milking herd was vaccinated. At that point, when $50 \%$ vaccination coverage was reached, cows that were due to calve were randomly assigned to be vaccinated or left as negative controls. Vaccination of cows was done according to label, with a total of three vaccine doses, with the first injection at 45 days before the expected parturition date, the second injection 35 days thereafter (corresponding to 10 days before the expected parturition date), and the third injection 62 days after the second injection (equivalent to 52 days post-parturition). The vaccine efficacy for the rate of new infections was relatively low and depending on the parity. For heifers, the vaccine efficacy for transmission was 25\%, indicating that the new infection rate was $25 \%$ lower in vaccinated heifers than in nonvaccinated heifers. However, the vaccine efficacy for transmission was still positive but nonsignificant for animals in second lactation (+ 16\%) and even negative (-30\%) for animals in third or higher lactation. The latter suggests an even higher transmission and thus higher new infection rate in vaccinated animals than in nonvaccinated animals. The vaccine efficacy for cure was moderate with a value of $41 \%$, meaning that the cure rate of $S$. aureus infections in vaccinated animals was $41 \%$ higher than in nonvaccinated animals. The latter resulted in a shorter duration of $S$. aureus infections. Still, a significant difference in vaccine efficacy for cure was present between the two herds. Combining the transmission parameter and cure rate parameter into the overall basic reproduction ratio, $\mathrm{R}_{0}$, resulted in a value of 0.89 for vaccinated animals and a value of 1.72 for control cows. For NAS, the $\mathrm{R}_{0}$ value for vaccinated animals was 0.91 and 1.40 for control animals. For both NAS and $S$. aureus, vaccination resulted in moving the basic reproduction ratio from above to below the threshold of one. The overall vaccine efficacy was estimated at $45 \%$.

In an experimental clinical trial including eight clinically healthy heifers and cows, four animals were vaccinated with $\operatorname{Startvac}^{\otimes}$ (Hipra S.A., Girona, Spain) at 45 days and 10 days before calving (PIEPERS et al., 2017). At 15 days after calving, two contralateral quarters of each of the eight animals were challenged with $2 \times 10^{9} \mathrm{cfu} / \mathrm{ml}$ of the formaldehyde-killed $S$. aureus 
strain. The other two quarters were infused with a phosphate buffered solution and served as control quarters. Blood samples were collected at 45 days before calving, 10 days before calving and 15 days after calving just before inoculation. Quarter milk samples were collected at two hours before inoculation and four hours, 12 hours, 24 hours and 48 hours after inoculation. All animals remained clinically healthy during the trial period. Twelve hours post-challenge, all quarters inoculated with the killed $S$. aureus strain were PCR-positive for S. aureus. Still, quarters from vaccinated animals had odds up to 20 times higher to be free of $S$. aureus two days post-challenge than nonvaccinated animals. In the nonvaccinated group, the average daily milk yield tended to decrease from $34.2 \mathrm{~kg} /$ day at 15 days after calving to $30.5 \mathrm{~kg}$ per day at 16 days after calving. In the vaccinated group, no significant difference in the average daily milk yield was observed over time. On the contrary, the average daily milk yield even increased from $33.7 \mathrm{~kg}$ per day at 15 days after calving to $36.5 \mathrm{~kg}$ per day at 16 days after calving. Interestingly, in the nonvaccinated animals, $S$. aureus-challenged quarters had a significantly higher somatic cell count than the control quarters whereas in the vaccinated group, the quarter milk somatic cell count was not significantly different from the quarter milk somatic cell count in the control quarters. The milk neutrophil viability was significantly higher in the $S$. aureus-challenged quarters than in the control quarters though was not influenced by the vaccination status of the animal. The blood concentration of both SAAC- and J5-specific antibodies increased between 45 days before the expected calving date and 15 days after calving in the vaccinated animals only. Consequently, vaccinated animals had significantly higher SAAC- and J5-specific antibody blood concentrations at 15 days after calving (pre-challenge) than the nonvaccinated animals. The milk concentration of SAAC-specific antibodies was significantly higher in vaccinated animals than in nonvaccinated animals, independently from the inoculation status of the quarters and the time of sampling. The latter findings support the results of Prenafeta et al. (2010). The higher anti-SAAC blood concentrations suggest a more pronounced humoral specific immune response which might explain the shorter duration of the $S$. aureus infections as was found in the study of Schukken et al. (2014). Also, the higher anti-SAAC concentrations in milk might potentially trigger the opsonization of the inoculated $S$. aureus bacteria and partly explain why vaccinated animals suffered from a less severe inflammatory reaction than the nonvaccinated animals. In this regard, Camussone et al. (2014) immunized 17 pregnant heifers with one of two vaccine formulations composed of either $S$. aureus whole or lysed cells formulated with Immune Stimulation Complex Matrix (ISCOM matrix). Both immunogens induced a strong humoral immune response in blood and milk characterized by a substantial increase in antibody concentration. Neutrophil phagocytosis was much more pronounced in the vaccinated animals than in the nonvaccinated ones, suggesting an increased opsonization of the $S$. aureus bacteria in case of increased antibody concentrations. The milk concentration of J5-specific antibodies observed in vaccinated animals was not significantly different at 15 or at 17 days after calving. Vaccination with Startvac ${ }^{\circ}$ (Hipra S.A., Girona, Spain) evoked a shift primarily toward the IgG1 antibody subtype (Th2-response). The IgG1 antibodies are well-known for their strong opsonizing capacity facilitating the recognition of the bacteria by the immune cells as well as their phagocytosis and killing by those immune cells. Regarding the response against $E$. coli, a weak though significant increase in J5-specific IgG2 concentrations (Th1-response) was observed.

\section{Vaccine efficacy against $E$. coli}

Despite the development of several vaccines against $E$. coli mastitis in the 1980 s, based on the J5 E. coli mutant, such vaccines to date, although demonstrating an ability to reduce the severity of clinical signs and duration of infection, have failed to 
demonstrate a reduction in the rate of new intramammary infections (HOGAN et al., 1992; WILSON et al., 2007a). Investigation of the use of J5 coliform vaccines has also demonstrated a positive effect on production in a way that vaccinated cows have been shown to recover milk yield after a clinical case more quickly than unvaccinated cows (WILSON et al., 2007b, 2008, 2009). The latter research group also provided evidence that increased production of both J5-specific IgG1 and IgG2 antibodies are relevant mechanisms of J5 vaccine protection, including the production of a higher proportion of IgG2 in vaccinated animals than in non-vaccinates which points towards a Th1-response. A significant constraint on the use of $E$. coli mastitis vaccines has been the relatively onerous vaccination regimens necessary to achieve the desired level of efficacy. These often necessitate vaccination both before and after calving. This has led to the development of more practical, farmer-friendly approaches to vaccination when J5 core antigen vaccines have been deployed in the field, such as a rolling schedule of vaccination of all cows in the herd on a quarterly basis. In a recent study, the efficacy of a multivalent mastitis vaccine in the control of bovine mastitis under UK field conditions using both the label regimen and a schedule of quarterly vaccination (BRADLEY et al., 2015). 3,130 cows were recruited between September 2010 and January 2012 to develop this study, from seven farms in the southwestern United Kingdom, and were randomly allocated, within farm, to one of three groups. The first group received the vaccine (Startvac ${ }^{\oplus}$, Hipra S.A., Girona, Spain) following the label regimen, the second group was vaccinated every $90 \mathrm{~d}$ following an initial vaccination course, and the third group was left unvaccinated to act as controls. Vaccine efficacy was assessed in the first $120 \mathrm{~d}$ of lactation. No strict criteria were applied pertaining to bulk milk somatic cell count or clinical mastitis incidence. All cows and heifers approaching their first calving were eligible for recruitment to the study, contingent on being in good health, having four functional quarters, teats free of significant teat lesions, and an estimated calving date to allow vaccination at predicted times before calving. Data were available for analysis from 1,696 lactations in 1,549 cows. In total, 779 cases of clinical mastitis occurred in the three study groups, and no significant differences were observed in the incidence or prevalence of clinical or subclinical mastitis between any of the three groups. Mastitis vaccination following the label regimen was associated with a significant reduction in the severity of clinical cases. Cows in this group were at significantly decreased odds of developing moderate to severe clinical mastitis (i.e. more than just visual changes of the milk). When the analysis was extended with the effect of vaccination on culling to encompass the first $305 \mathrm{~d}$ of lactation, this revealed a significant difference in the total number of cows culled between the treatment groups, with 26.2, 18.3 , and $24.2 \%$ of cows being culled in the unvaccinated, label, and rolling groups, respectively. Significantly fewer cows were culled from the label group than from either the unvaccinated or the rolling groups. Analysis of milk production data demonstrated that, on average, cows on the label regimen produced a higher volume of milk $(231 \mathrm{~L})$ and more milk solids $(12.36 \mathrm{~kg})$ than unvaccinated cows in the first $120 \mathrm{~d}$ of lactation.

\section{Other alternatives}

\section{Bacteriophages}

Bacteriophage therapy can be an alternative to antibiotics in the fight against intramammary infections. Bacteriophages are viruses able to infect and kill bacteria (CHIBANI-CHENNOUFI et al., 2004). Phages were demonstrated to yield potential as new antimicrobial agents for veterinary applications. One of the well-known bacteriophages is Phage $K$, an antistaphylococcus phage, with lytic and antimicrobial action. Phage $K$ has been used as prophylactic measure against intramammary infections caused by $S$. aureus. One of the main disadvantages of the latter phage is, however, that it is inhibited by milk and udder 
secretions (O'FLAHERTY et al., 2005). Other virulent phages with an anti-staphylococcal activity are MSA6 (KWIATEK et al., 2012) and $\mathrm{CHAP}_{k}$ (FENTON et al., 2013). CHAP $_{k}$ showed effectiveness against biofilms either by preventing biofilm formation or by disrupting established biofilms of staphylococcal strains associated with bovine mastitis.

\section{Nanoparticles}

Nanoparticles can be used as delivery vehicles for antimicrobial agents. Several researchers demonstrated that nanoparticles have potential as an alternative for the treatment of bovine mastitis. As an example, it has been demonstrated that silver nanoparticles inhibited $S$. aureus bacteria isolated from milk samples of cows with subclinical mastitis (DEHKORDI et al., 2011). The synergistic effect of silver nanoparticles and antibiotics has been evaluated as well. A combination of the antimicrobial erythromycin with silver nanoparticles was found to be successful against S. aureus in in vitro work of Kazemi et al. (2014). Other nanoparticles showing potential as alternative treatment for $S$. aureus intramammary infections are the tilmicosin-solid lipid nanoparticles (WANG et al., 2012) as well the amoxicillin nanoparticles that were demonstrated to be biologically active against S. aureus, E. coli and Streptococcus agalactiae (XUEFENG et al., 2009). Cardozo et al. (2014) revealed that nitric oxidenanoparticles were able to inhibit $S$. aureus, and in general could be used in the treatment and prevention of bovine mastitis.

\section{Cytokines}

The emergence of antibiotic resistance has prompted the investigation of the immunotherapeutic use of recombinant cytokines in the treatment of bovine mastitis. Cytokines are small proteins that have an important role in cell signaling. Some cytokines (such as IL-2, IFN- $\gamma$, and TNF- $\alpha$ ) are responsible for stimulating innate and acquired immunity in the mammary gland. Unfortunately, the enhanced immunity was not adequate to successfully treat bovine mastitis. When combined with antibiotics, however, an additive effect was found, suggesting a synergistic effect and potential applications of cytokines as adjuvant in mastitis therapy (ALLUWAIMI, 2004). A more recent cytokine-derived molecule that has been investigated and is now commercially available is pegbovigrastim. Pegbovigrastim is the pegylated form of the cytokine bovine granulocyte colony stimulation factor. The cytokine bovine granulocyte colony stimulating factors is a cytokine that regulates the growth and differentiation of the precursor cell in the bone marrow committed to forming neutrophils. PEGylation increases the half-life of the protein messenger molecule from hours to days. In a very recent study of Canning et al. (2017), pegbovigrastimtreated animals exhibited a $35 \%$ decrease in the incidence of clinical mastitis relative to controls during the first 30 days of lactation (Figure 1).

\section{Homeopathy}

Homeopathy was developed by the German physician Samuel Hahneman (1810) and is commonly referred to as a "complementary or alternative medicine". Producers see advantages in the use of homeopathic remedies to avoid milk withdrawal periods (BOLDYREVA, 2003), milk residues (ENBERGS, 1998), or development of antibiotic resistance (SMITH, 2002). Still, scientific evidence for the effectiveness of homeopathy is lacking. Recent studies in veterinary medicine focused on the difference of the cure risk between therapy and control groups. While some studies found no effects of homeopathic therapy for mastitis (HEKTOEN, 2004; WERNER et al., 2010), other studies showed negative results in the homeopathic group (GARBE et al., 2000; VARSHNEY; NARESH, 2005), and still others showed positive results (DAY, 1986; MERCK et al., 1989). In a meta-analysis of Mathie and Clausen (2015), no significant differences were found between homeopathic and conventional therapies in veterinary medicine. Interestingly, many of the studies included 
in the meta-analysis lacked a proper scientific approach. Only $28 \%$ of the studies using homeopathy in veterinary medicine were randomized and placebocontrolled (CLAUSEN et al., 2013). In a very recently executed triple-blind, randomized controlled trial, the specific treatment effects of homeopathic mastitis in dairy cows was investigated. However, no significant differences were observed in time to recovery, somatic cell count, risk of clinical cure within 14 days after disease occurrence, mastitis recurrence risk, or culling risk. The results indicated no additional effect of homeopathic treatment compared with placebo (EBERT et al., 2017). The findings are in accordance with those obtained in a meta-analysis study conducted by Dufour and co-workers who concluded that homeopathic treatments are not efficient for management of clinical mastitis (DUFOUR et al., 2017).

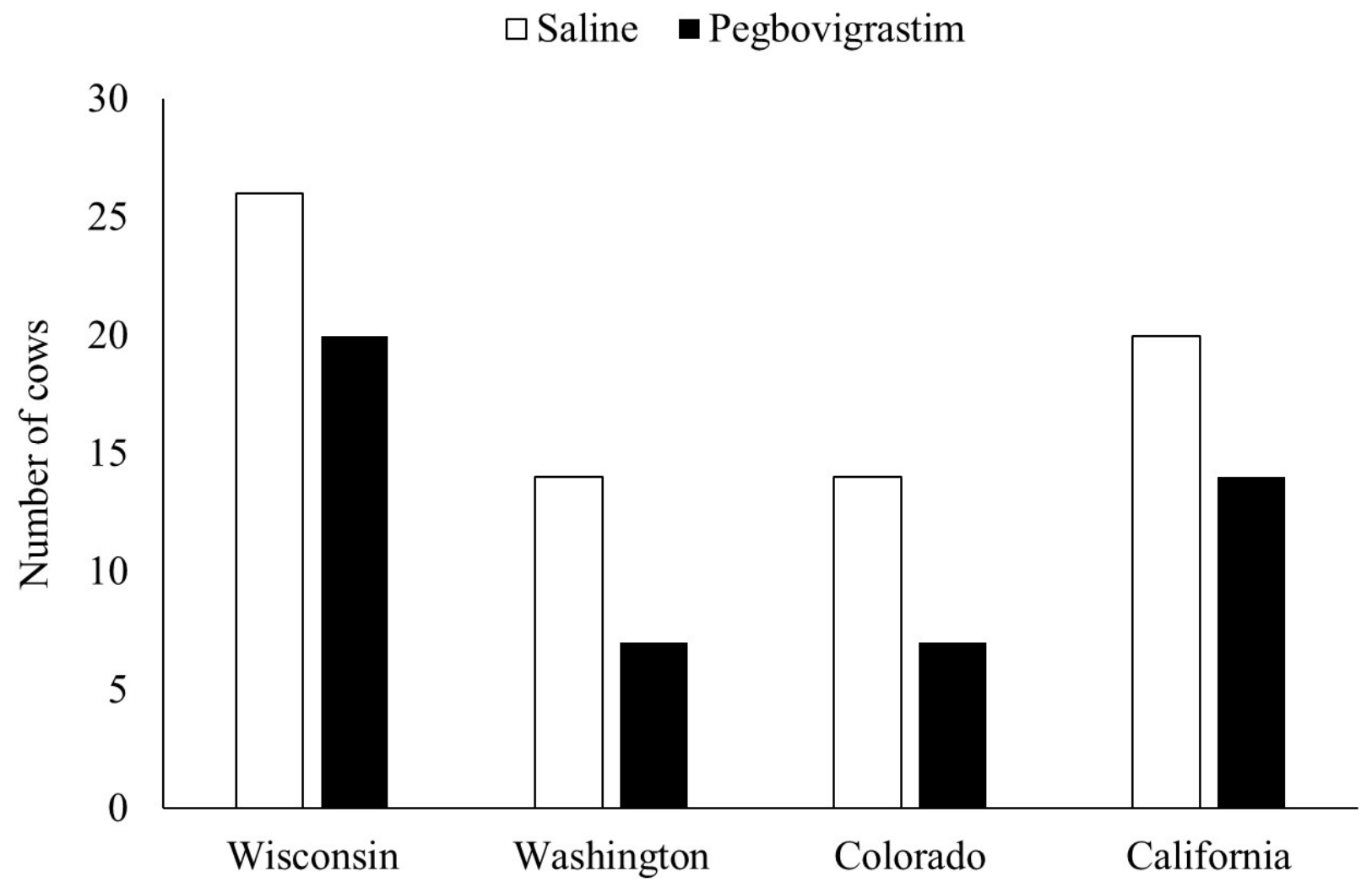

Figure 1 - Effect of pegbovigrastim on number of periparturient cows and heifers suffering from clinical mastitis at four United States dairies

Source: adapted from Canning et al. (2017)

\section{Bacteria and bacteria-derived inhibitory substances}

Several researchers suggest natural compounds produced by bacteria and presenting antimicrobial action as potential alternatives for antibiotics in the treatment of bovine mastitis. In 2003, field observations of De Vliegher et al. (2003) suggested that teat apex colonization by Staphylococcus chromogenes prepartum in dairy heifers protects the udder quarters against elevated somatic cell count. Interestingly, two out of $10 \mathrm{~S}$. chromogenes isolates, both originating from two different teats from the same heifer, consistently inhibited growth of all $S$. aureus, Streptococcus dysgalactiae, and S. uberis strains, but none of the E. coli strains in vitro (DE VLIEGHER et al., 2004). Staphylococcus chromogenes belongs to the heterogenous group of NAS and is one of the five most prevalent NAS causing intramammary infections in bovine (VANDERHAEGHEN et al., 2015). Piccart et al. (2016) recently found that lactic acid bacteria 
recovered from honeybees inhibited the in vitro growth of all major mastitis pathogens. Even the mastitis pathogens that were displaying antimicrobial resistance to one or more antimicrobial compounds were inhibited to some extend by the honey and lactic acid bacteria. Also, Bouchard et al. (2013) found that live Lactobacillus casei were able to prevent the internalization of $S$. aureus into mammary epithelial cells. Nisin (SEARS et al., 1992), Lacticin 3147 (TWOMEY et al., 2000) (Figure 2) and lysostaphin (HENG et al., 2007) are bacteriocins that have shown to be effective against $S$. aureus.

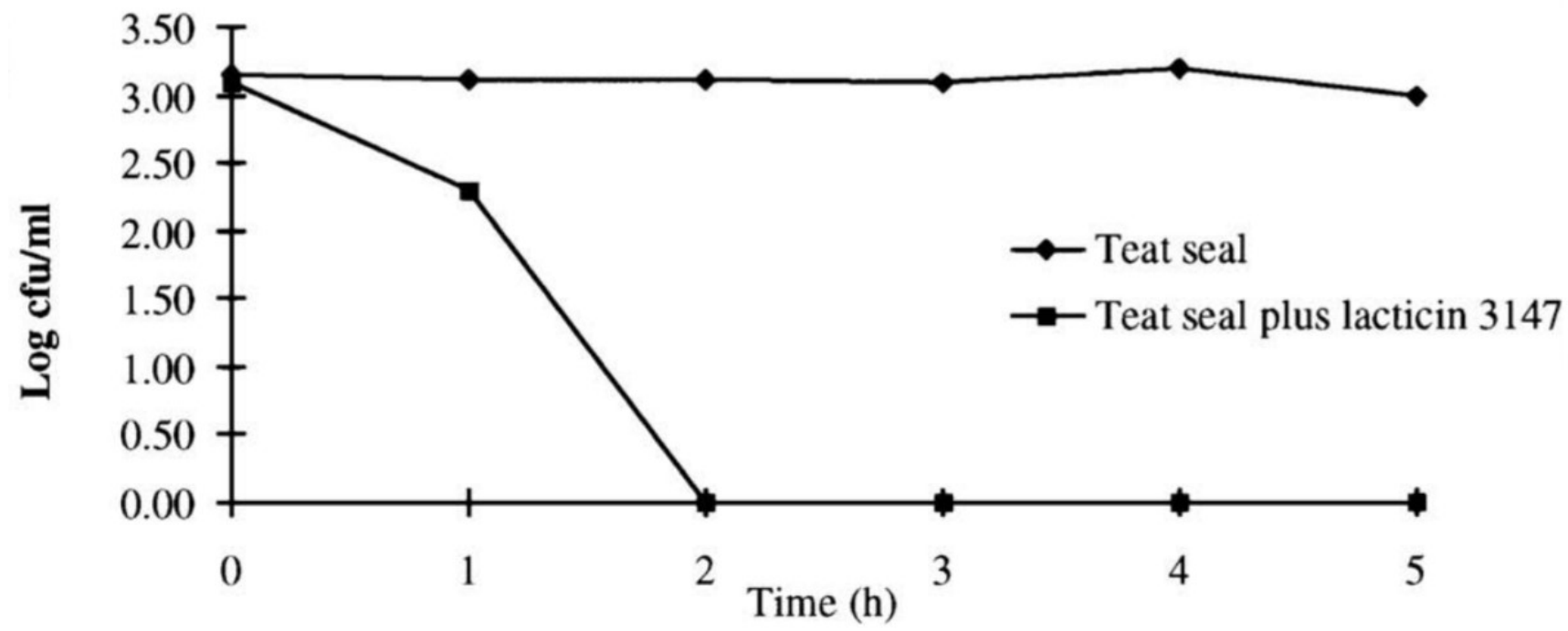

Figure 2 - The inhibitory effect of teat seal plus lacticin 3147 against Staphylococcus aureus DPC5246 resuspended in buffer at $\mathrm{pH} 7.0$

Source: based on Twomey et al. (2000)

\section{Animal-derived inhibitory substances}

The use of immunomodulators, naturally produced by mammals, as potential non-antibiotic antimicrobial agents for the treatment and prevention of bovine mastitis has also received attention. Lactoferrin is probably the most well-known natural immunomodulator. Lactoferrin is a glycoprotein found in several body secretions such as saliva, tears, bronchial mucus, and milk. This molecule exhibits an antibacterial effect against some major mastitis- causing pathogens namely E. coli, S. aureus, Pseudomonas aeruginosa and Klebsiella pneumonia, and also NAS (HAFEZ et al., 2013) (Figure 3). Another example is recombinant bovine soluble CD14. Recombinant bovine soluble CD14 reduced the severity of experimental E. coli mastitis in mice (LEE et al., 2003). There is increasing evidence that the soluble form of CD14 competes with membrane-bound CD14 for lipopolysaccharide and plays a pivotal role in regulating bacterial infection and septic shock caused by Gram-negative bacteria (LEE et al., 2003). 

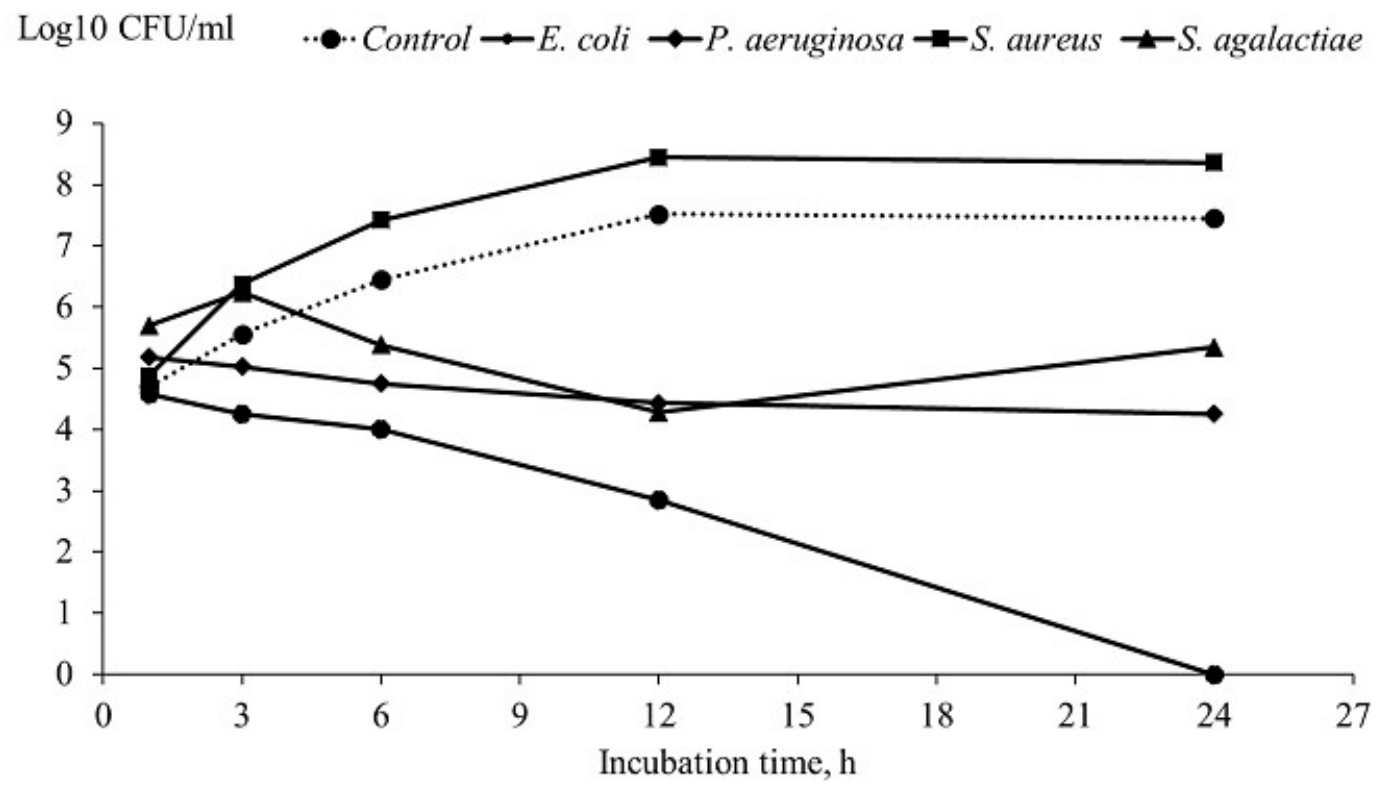

Figure 3 - Antimicrobial effect of bovine lactoferrin on E. coli, S. aureus, Streptococcus agalactiae and Pseudomonas aeruginosa counts after $1,3,6,12$, and $24 \mathrm{~h}$ of incubation

\section{Plant-derived inhibitory substances and medium-chain fatty acids}

Plants are promising sources of new biologically active agents with antimicrobial action. One of the major advantages of plant-derived drugs is that they do not induce resistance after prolonged exposure (DOMADIA et al., 2007). Some examples of plantderived natural compounds are diterpenes (FONSECA et al., 2013), trans-cinnamaldehyde, eugenol, carvacrol, and thymol (BASKARAN et al., 2009). All show antibacterial activity against the major mastitis pathogens including S. agalactiae, S. dysgalactiae, $S$. uberis, S. aureus, and E. coli.

MCFA are another form of plant-derived antimicrobials. MCFA are derived from mediumchain triglycerides. Natural sources rich in mediumchain fatty acids are coconut oil, palm kernel oil and camphor tree drupe. Coconut oil is composed of approximately $66 \%$ of medium-chain triglycerides. Horse milk is another rich source of medium-chain triglycerides. On the contrary, the milk fats of humans, dogs and guinea pigs are largely made up of long-chain fatty acids (BRECKENRIDGE; KUKSIS, 1967). The milk fats of cows, sheep and goats are primarily rich in short-chain fatty acids. MCFA and the corresponding number of carbons found in medium-chain triglycerides are caproic acid (C6), caprylic acid (C8), capric acid (C10) and lauric acid (C12). Caprylic, capric and lauric acid have been extracted as well, although in relatively small amounts, from the teat keratin lining the teat canal (TREECE et al., 1966). Besides the microbicidal activity, in humans there is increasing evidence that MCFA have immunomodulating activities.

A substantial body of literature exists on the antimicrobial properties of free medium- and longchain fatty acids and their monoglycerides that exert antimicrobial activity towards an array of pathogenic micro-organisms. Still, information on their efficacy in killing mastitis-causing bacteria is limited. Probably the first study that provided some information published on the microbicidal activity of long-chain fatty acids which are naturally present in the teat canal keratin towards several common mastitis pathogens was that of Hogan et al. (1987). A more recent study specifically investigated the efficacy of the MCFA caprylic acid (C8), and its monoglyceride, monocaprylin, to inactivate a number of mastitis 
pathogens, including S. agalactiae, S. dysgalactiae, $S$. uberis, S. aureus, and E. coli (NAIR et al., 2005). Populations of surviving bacteria were determined at 0 $\min , 1 \mathrm{~min}, 6 \mathrm{~h}, 12 \mathrm{~h}$, and $24 \mathrm{~h}$ of incubation at a temperature of $39^{\circ} \mathrm{C}$. Both caprylic acid and monocaprylin reduced growth of all five pathogens $>$ $5.0 \log \mathrm{cfu} / \mathrm{mL}$ after $6 \mathrm{~h}$ of incubation (Figure 4). Interestingly, the microbicidal activity of fatty acids decreases with increasing chain length, with MCFA exhibiting stronger activity than long-chain fatty acids (WANG; JOHNSON, 1992; ISAACS et al., 1995). The decreasing effectiveness with longer chain length is most probably related to increased hydrophobicity and decreased solubility. Inhibitory fatty acids must be sufficiently water soluble to reach an effective concentration in the aqueous solution and yet be sufficiently hydrophobic to interact with hydrophobic proteins or lipids on the bacterial cell surface (WANG; JOHNSON, 1992). The latter reasoning might hold true for the different MCFA mutually as well (NAIR et al., 2005).

\section{$\log$ CFU/ml}

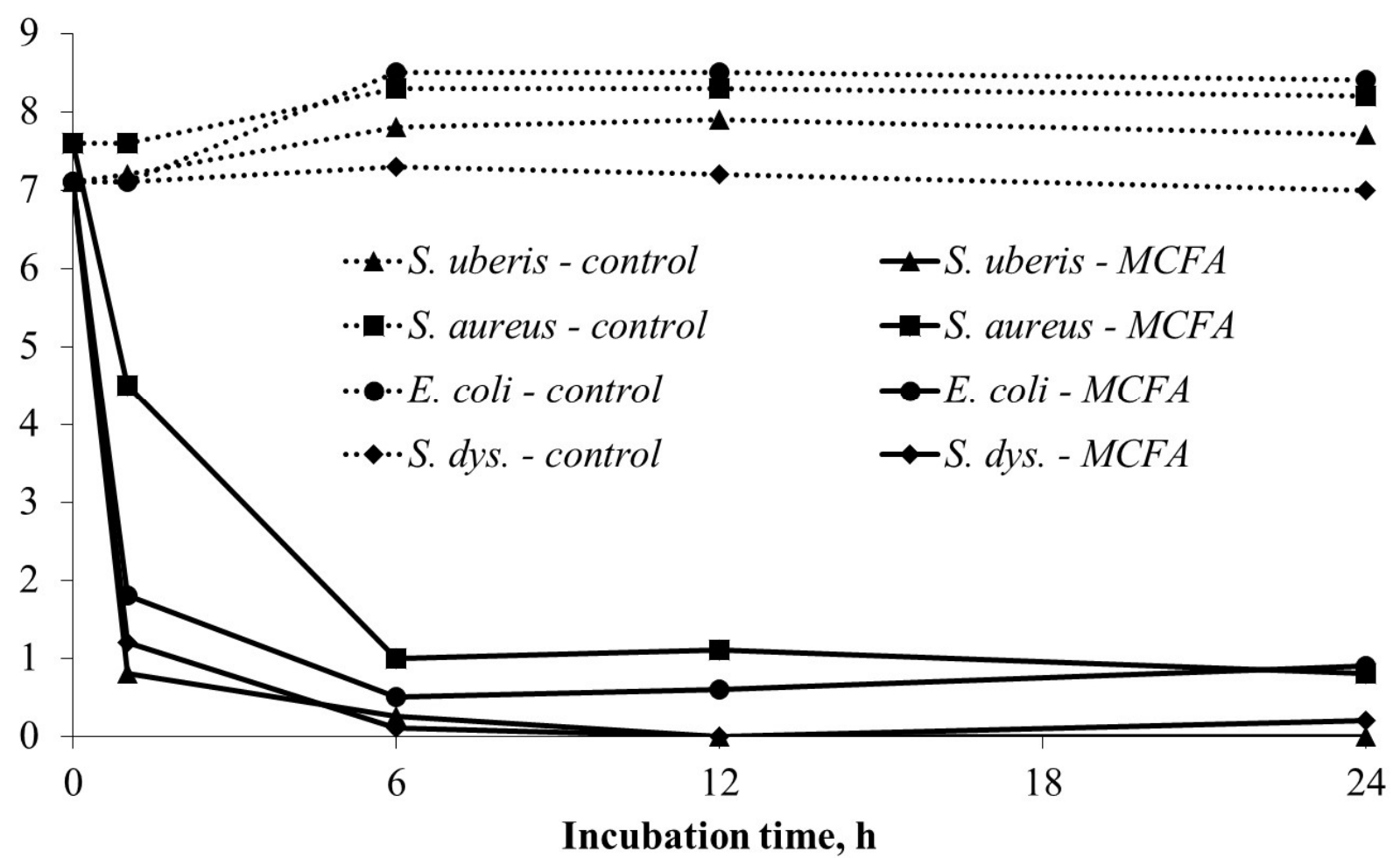

Figure 4 - Effect of $50 \mathrm{mM}$ of the medium-chain fatty acid (MCFA) caprylic acid on Streptococcus uberis, Staphylococcus aureus, Escherichia coli and Streptococcus dysgalactiae in milk. Surviving bacterial populations (expressed in $\log \mathrm{cfu} / \mathrm{mL}$ ) in milk samples stored at $39^{\circ} \mathrm{C}$ for $24 \mathrm{~h}$ were enumerated at specified time points on tryptic soy agar plates containing $0.6 \%$ yeast extract

Source: adapted from Nair et al. (2005) 
The exact mechanism behind the bactericidal activity of free fatty acids on bacteria has not yet been unraveled. Cellular membranes have long been regarded as a primary target for antimicrobial fatty acids. Monoglycerides have been demonstrated to penetrate into the bacteria as non-ionic surfactants and to incorporate themselves into the bacterial plasma membrane, thereby altering membrane permeability and affecting transport of nutrients. Electron microscopic studies with 43 bacterial cells exposed to monoglycerides have shown plasma membrane disintegration leaving the peptidoglycan cell wall intact (BERGSSON et al., 1998). Other studies indicated that micromolar concentrations of fatty acids can affect the activity of enzymes in the cell membrane (WARTH, 1989; VIEGAS; SACORREIA, 1991). MCFA, in particular, have also been hypothesized to diffuse into bacterial cells in their undissociated form and dissociate within the protoplasm, thereby leading to intracellular acidification (SUN et al., 2002). A lower intracellular $\mathrm{pH}$ can lead to inactivation of intracellular enzymes (VIEGAS; SA-CORREIA, 1991), and inhibition of amino acid transport (FREESE et al., 1973). At sublethal concentrations, monoglycerides such as monolaurin can interfere with bacterial signal transduction, and inhibit the expression of virulence factors and antibiotic resistance genes (PROJAN et al., 1994; RUZIN; NOVICK, 1998).

The sensitivity to fatty acids seems to vary among bacterial species and possibly also among strains within a species. In general, Gram-negative bacteria like E. coli are less sensitive to the antimicrobial effect of fatty acids and monoglycerides than Grampositive bacteria (KABARA, 1978; MONK et al., 1996). Also, S. aureus seems to be more tolerant than mastitis-causing streptococci such as S. agalactiae, $S$. dysgalactiae, and S. uberis (NAIR et al., 2005). In the latter study, caprylic acid at $100 \mathrm{Mm}$ and monocaprylin at $50 \mathrm{mM}$ levels resulted in a rapid decline (4 to $6 \log \mathrm{cfu} / \mathrm{ml}$ ) in the populations of streptococci after $1 \mathrm{~min}$ of treatment. At the same time point, the effect of monocaprylin on E. coli and S. aureus was clearly less pronounced (3 to $4 \log$ $\mathrm{cfu} / \mathrm{ml})$. The comparatively lesser instantaneous antibacterial effect of MCFA on Gram-negative bacteria can possibly be attributed to the well-known differences in cell wall structure between Grampositive and Gram-negative bacteria. With respect to S. aureus, it is well established that some strains are able to produce slime once they start growing (SUTRA et al., 1990). It is very plausible that the layer of exopolysaccharide or pseudocapsule slime surrounding them could interfere with the lipids coming in direct contact with the bacterial cell membranes and exerting the antimicrobial activity.

The inhibitory activity of fatty acids and monoglycerides probably also depends on the composition of the medium in which they are supposed to act. Wang and Johnson (1992) found that although lauric acid and its monoglyceride monolaurin were bactericidal against Listeria monocytogenesis in brain-heart infusion broth, none of the two were still inhibitory in milk. Certain nutrients in relatively high concentrations such as lipophilic proteins (e.g. albumin), fat globules, starch, or others could interact with fatty acids and thereby decrease their bioavailability (KABARA, 1978). Glassman (1949) reported that proteins reduce the bactericidal activity of surface-active agents like monoglycerides due to the formation of lipid-protein complexes. On the contrary, reduced antimicrobial activity of MCFA when evaluated in milk could not be observed by Nair et al. (2005).

The discrepancy in the findings between those two studies might again be due to differences in chain length between the MCFA that were tested. Caprylic acid, an 8-carbon MCFA, is less 
hydrophobic and potentially more soluble than lauric acid, a 12-carbon MCFA, and could therefore be more effective in killing bacteria under less optimal conditions, i.e. milk, than MCFA with a longer chain (NAIR et al., 2005).

Although a plethora of information is available on the immunomodulating effects of MCFA in humans, little information is available on these effects in the bovine. Piepers and De Vliegher (2013) explored the effect of commercially available orally supplemented MCFA (Aromabiotic ${ }^{\oplus}$, Vitamex n.v., Drongen, Belgium) to heifers and multiparous cows starting at 6 to 8 weeks prior to calving on the blood and milk neutrophil apoptosis at 1 to 3 days after calving in a double-blinded clinical trial. Neutrophils play an important role in the first line immune defense of the mammary gland (RAINARD et al., 2006). Apoptosis of bovine neutrophils implies an impaired phagocytotic and oxidative burst activity (MEHRZAD et al., 2004). A reduction in neutrophil apoptosis has therefore been proposed to be beneficial for the elimination of the bacteria in the early stages of intramammary infections as increased numbers of more viable neutrophils enhance the defense against the invading bacteria (DIBBERT et al., 1999). In this trial, twelve lactating cows and 10 end-term heifers were randomly assigned to either an untreated control $(\mathrm{n}=11)$ or MCFA supplemented (treated) group $(\mathrm{n}=11)$. Oral supplementation with MCFA started at dry-off for multiparous cows and 7 weeks prior to expected calving date for the end-term heifers. Interestingly, oral supplementation of MCFA to heifers and multiparous cows suppressed the natural drop in the systemic as well as the local innate immunity shortly after calving as evident from the better neutrophil quality in both blood and milk (Figure 5). In the control animals, blood neutrophil apoptosis significantly increased between start of supplementation and the first days after calving, whereas no substantial change in blood neutrophil apoptosis could be observed in the treated animals. Also, the proportion of apoptotic milk neutrophils in early lactation was lower in the treated group compared to the control group. The mechanism behind these potential immunomodulating effects is unknown and even more intriguing than the questions related to the microbicidal activity of MCFA. In humans, MCFA such as lauric acid seems to have moderate to strong antioxidant properties, delaying or even preventing cell/tissue damage due to oxidative stress (BELLINATIE-PIRES et al., 1993; HENRY et al., 2002; VERSLEIJEN et al., 2005). Oxidative stress is the result of an imbalance between increased production of reactive oxygen species (ROS) causing cell and tissue damage, and reduced availability of antioxidants usually protecting cells from the damaging effects of ROS. Besides their antioxidative activities, caprylic and lauric acid also exhibit anti-inflammatory properties via the inhibition of cyclo-oxygenase I (COX-I) and II (COX-II) (HENRY et al., 2002).

When looking at the potential applications of MCFA in practice, treatment of mastitis should be distinguished from prevention of mastitis:

Treatment of mastitis. The effectiveness of MCFA in inhibiting the most common mastitis pathogens under in vitro circumstances looks promising in view of the development of novel strategies in the control of mastitis. Similar to what has already been done with bacteriocins (RYAN et al., 1999), MCFA could be incorporated in intramammary infusions whether or not combined with internal teat sealants used at dry-off. Still, there is much more research required to ascertain the in vivo effectiveness as well as their potential negative effects on the udder tissue. In addition, MCFA might affect the organoleptic and functional properties of milk which would 
obviously make the use of MCFA as microbicidal less desirable (AL-SHABIBI et al., 1964). Oral supplementation of MCFA will most likely not affect the organoleptic properties of milk, but will, as a drawback, probably neither result in an increase of the antibacterial properties of milk. Grummer and Socha (1989) evaluated the effects of medium-chain triglycerides supplementation on milk fatty acid composition. Although changes in milk fatty acid composition were observed, they were minor and mostly unexplained. In contrast to long-chain fatty acids, which are absorbed via the lymphatic system as chylomicrons, MCFA are absorbed via the hepatic portal vein. As a consequence, the efficiency of transfer of absorbed MCFA to milk is low.

Prevention of mastitis. Oral supplementation of MCFA could offer an opportunity to stimulate cellular immunity and support cows in meeting their every-day challenges, particularly in the critical period around calving. Negative energy balance and increased milk production demands in high yielding dairy cows during transition often result in an accumulation of ROS that exceeds the antioxidant capabilities of the cow. The increased oxidative stress during transition has been proposed a number of times as a major underlying factor of the immunosuppression that cows suffer from around parturition (BERNABUCCI et al., 2005; CASTILLO et al., 2005; SORDILLO; AITKEN, 2009). As antioxidants, MCFA could possibly help in minimizing the detrimental effects of the excessive accumulation of ROS and thus keeping oxidative stress and negative effects on the cellular immune functions under control. Because of their antiinflammatory properties, MCFA could also be beneficial in channeling the sometimes overzealous inflammatory response to intramammary infections that occurs during transition, thereby limiting udder tissue damage and milk production losses (BURVENICH et al., 2007). However, further research is needed to value the relevance of both the anti-oxidative and anti-inflammatory effects of MCFA in terms of potential reduction of antibiotic usage on dairy farms in relation to udder health.

\section{Conclusions}

Currently, the administration of antimicrobials is still the most common method to treat bovine mastitis. Still, this kind of strategy has some important disadvantages including the potential development of antimicrobial resistance in both animal and human pathogens, and the risk for antimicrobial residues in milk. Therefore, a wide range of alternatives to antimicrobials have been investigated by several groups of researchers in order to find an effective and equivalent approach for the treatment of bovine mastitis. Bacteriophages, vaccines, nanoparticles, cytokines, and natural compounds of plants, animals and bacteria are some examples of potentially valid substitutes for antimicrobials. For most of those alternatives, in vitro studies showed encouraging results but more research, primarily conducted in vivo, is still lacking though critical and required. Currently, vaccination in the periparturient period against mastitis caused by E. coli and S. aureus, injection of pegbovigrastim in periparturient period and oral supplementation of MCFA across dry period are the only alternatives that have yet been shown to yield decent prevention, though not curative efficacy in vivo. 


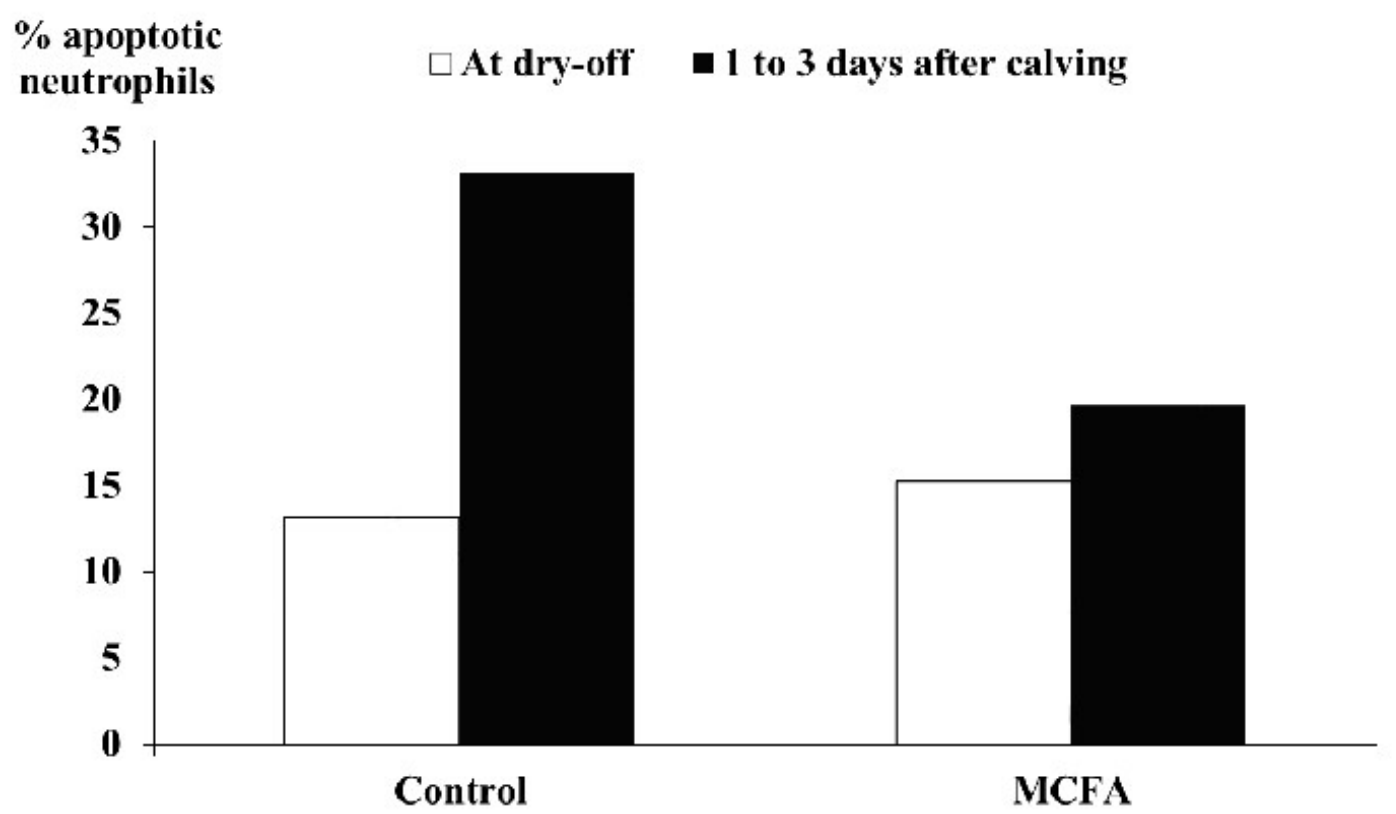

Figure 5 - Percentage apoptotic blood polymorphonuclear neutrophilic leukocytes in both control and medium-chain fatty acid (MCFA) supplemented animals between the start of supplementation [6-8 weeks before expected calving date (= at dry-off)] and early lactation (1-3 days in milk)

Source: adapted from Piepers and De Vliegher (2013)

\section{Reference}

ALLUWAIMI, A. M. The cytokines of bovine mammary gland: prospects for diagnosis and therapy. Research in Veterinary Science, v. 77, n. 3, p. 211-222, 2004. doi: 10.1016/j.rvsc.2004.04.006.

AL-SHABIBI, M. M. A.; LANGNER, E. H.; TOBIAS, J.; TUCKEY, S. L. Effect of added fatty acids on the flavor of milk. Journal of Dairy Science, v. 47, n. 3, p. 295-296, 1964. doi: 10.3168/jds.S0022-0302(64)88644-6.

BASKARAN, S. A.; KAZMER, G. W.; HINCKLEY, L.; ANDREW, S. M.; VENKITANARAYANAN, K. Antibacterial effect of plant-derived antimicrobials on major bacterial mastitis pathogens in vitro. Journal of Dairy Science, v. 92, n. 4, p. 1423-1429, 2009. doi: 10.3168/jds.2008-1384.

BELLINATI-PIRES, R.; WAITZBERG, D. L.; SALGADO, M. M.; CARNEIRO-SAMPAIO, M. M. S. Functional alterations of human neutrophils by medium-chain triglyceride emulsions - evaluation of phagocytosis, bacterial killing, and oxidative activity. Journal of Leukocyte Biology, v. 53, n. 4, p. 404-410, 1993. doi: 10.1002/jlb.53.4.404.

BERGSSON, G.; ARNFINNSSON, J.; KARLSSON, S. M.; STEINGRIMSSON, O.; THORMAR, H. In vitro inactivation of Chlamydia trachomatis by fatty acids and monoglycerides. Antimicrobial Agents and Chemotherapy, v. 42, n. 9, p. 2290-2294, 1998.

BERNABUCCI, U.; RONCHI, B.; LACETERA, N.; NARDONE, A. Influence of body condition score on relationships between metabolic status and oxidative stress in periparturient dairy cows. Journal of Dairy Science, v. $88, \quad$ n. 6 , p. 2017-2026, 2005. doi: 10.3168/jds.S0022-0302(05)72878-2.

BOLDYREVA, E. M. Mastitis of cows and the use of homeopathy for the treatment. In: European Association for Animal Production Annual, 54. 2003, Rome. 
Proceedings... Rome: European Association for Animal Production, 2003. 258 p.

BOUCHARD, D. S.; RAULT, L.; BERKOVA, N.; LE LOIR, Y.; EVEN, S. Inhibition of Staphylococcus aureus invasion into bovine mammary epithelial cells by contact with live Lactobacillus casei. Applied and Environmental Microbiology, v. 79, n. 3, p. 877-885, 2013. doi: 10.1128/AEM.03323-12.

BRADLEY, A. J. Bovine mastitis: an evolving disease. Veterinary Journal, v. 164, n. 2, p. 116-128, 2002. doi: 10.1053/tvjl.2002.0724.

BRADLEY, A. J.; BREEN, J. E.; PAYNE, B.; WHITE, V.; GREEN, M. J. An investigation of the efficacy of a polyvalent mastitis vaccine using different vaccination regimens under field conditions in the United Kingdom. Journal of Dairy Science, v. 98, n. 3, p. 1706-1720, 2015. doi: $10.3168 /$ jds.2014-8332.

BRECKENRIDGE, W. C.; KUKSIS, A. Molecular weight distributions of milk fat triglycerides from seven species. Journal of Lipid Research, v. 8, n. 5, p. 473-478, 1967.

BURTON, J. L.; MADSEN, S. A.; YAO, J.; SIPKOVSKY, S. S.; COUSSENS, P. M. An immunogenomics approach to understanding peripartiurient immunosuppression and mastitis susceptibility in dairy cows. Acta Veterinaria Scandinavica, v. 42, n. 3, p. 407-424, 2001.

BURVENICH, C.; BANNERMAN, D. D.; LIPPOLIS, J. D.; PEELMAN, L.; NONNECKE, B. J.; KEHRLI, M. E.; PAAPE, M. J. Cumulative physiological events influence the inflammatory response of the bovine udder to E. coli infections during transition period. Journal of Dairy Science, v. 90, p. E39-54, 2007. Supplement 1. doi: 10.3168/jds.2006-696.

CAMUSSONE, C.; VEAUTE, C. M.; PUJATO, N.; MOREIN, B.; MARCIPAR, I. 2014. Immune response of heifers against Staphylococcus aureus CP5 whole cell and lysate vaccine formulated with ISCOM Matrix adjuvant. Research in Veterinary Science, v. 96, n. 1, 86-94, 2014. doi: 10.1016/j.rvsc.2013.10.004.

CANNING, P.; HASSFURTHER, R.; TERHUNE, T.; ROGERS, K.; ABBOTT, S.; KOLB, D. Efficacy and clinical safety of pegbovigrastim for preventing naturally occurring clinical mastitis in periparturient primiparous and multiparous cows on US commercial dairies. Journal of Dairy Science, v. 100, n. 8, p. 6504-6515, 2017. doi: $10.3168 /$ jds.2017-12583.

CARDOZO, V. F.; LANCHEROS, C. A.; NARCISO, A. M.; VALERETO, E. C.; KOBAYASHI, R. K.; SEABRA, A. B.; NAKAZATO, G. Evaluation of antibacterial activity of nitric oxide-releasing polymeric particles against Staphylococcus aureus and Escherichia coli from bovine mastitis. International Journal of Pharmaceutics, v. 473, n. 1-2, p. 20-29, 2014. doi: 10.1016/j.ijpharm.2014.06.051.

CASTILLO, C.; HERNANDEZ, J.; BRAVO, A.; LOPEZALONSO, M.; PEREIRA, V.; BENEDITO, J. L. Oxidative status during late pregnancy and early lactation in dairy cows. Veterinary Journal, v. 169, n. 2, p. 286-292, 2005. doi: 10.1016/j.tvjl.2004.02.001.

CHIBANI-CHENNOUFI, S.; DILLMAN, M. L.; MARVIN-GUY, L.; RAMI-SHOJAEI, S.; BRÜSSOW, H. Lactobacillus plantarum bacteriophage LP65: a new member of SPO1-like genus of the family Myoviridae. Journal of Bacteriology, v. 186, n. 21, p. 7069-7083, 2004. doi: 10.1128/JB.186.21.7069-7083.2004.

CLAUSEN, J.; ALBRECHT, H.; MATHIE, R. T. Veterinary clinical research database for homeopathy: placebo-controlled trials. Complement Therapies in Medicine, v. 21, n. 2, p. 115120, 2013. doi: 10.1016/j.ctim.2012.11.009.

DAY, C. Clinical trials in bovine mastitis. Use of nosodes for prevention. British Homoeopathic Journal, v. 75, n. 1, p. 11-14, 1986.

DE VLIEGHER, S.; LAEVENS, H.; DEVRIESE L. A.; OPSOMER, G.; LEROY, J. L. M.; BARKEMA, H. W.; DE KRUIF, A. Prepartum teat apex colonization with Staphylococcus chromogenes in dairy heifers is associated with low somatic cell count in early lactation. Veterinary Microbiology, v. 92, n. 3, p. 245-252, 2003. doi: 10.1016/S0378-1135(02)00363-2.

DE VLIEGHER, S.; OPSOMER, G.; VANROLLEGHEM, A.; DEVRIESE, L. A.; SAMPIMON, O. C.; SOL, J.; BARKEMA, H. W.; HAESEBROUCK, F.; DE KRUIF, A. In vitro growth inhibition of major mastitis pathogens by Staphylococcus chromogenes originating from teat apices of dairy heifers. Veterinary Microbiology, v. 101, n. 3, p. 215-221, 2004. doi: 10.1016/j.vetmic.2004.03.020.

DEHKORDI, S. H.; HOSSEINPOUR, F.; KAHRIZANGI, A. E. An in vitro evaluation of antibacterial effect of silver 
nanoparticles on Staphylococcus aureus isolated from bovine subclinical mastitis. African Journal of Biotechnology, v. 10, n. 52, p. 10795-10797, 2011. doi: 10.5897/AJB11.1499.

DENIS, M.; WEDLOCK, D. N.; LACY-HULBERT, S. J.; HILLERTON, J. E.; BUDDLE, B. M. Vaccines against bovine mastitis in the New Zealand context: What is the best way forward? New Zealand Veterinary Journal, v. 57, n. 3, p. 132140, 2009. doi: 10.1080/00480169.2009.36892.

DIBBERT, B.; WEBER, M.; NIKOLAIZIK, W. H.; VOGT, P.; SCHONI, M. H.; BLASER, K.; SIMON, H. U. Cytokinemediated Bax deficiency and consequent delayed neutrophil apoptosis: a general mechanism to accumulate effector cells in inflammation. Proceedings of National Academy of Sciences of the United States of America, v. 96, n. 23, p. 13330-13335, 1999.

DOMADIA, P.; SWARUP, S.; BHUNIA, A.; SIVARAMAN, J.; DASGUPTA, D. Inhibition of bacterial cell division protein FtsZ by cinnamaldehyde. Biochemical Pharmacology, v. 74, n. 6, p. 831-840, 2007. doi: 10.1016/j.bcp.2007.06.029.

EBERT, F.; STAUFENBIEL, R.; SIMONS, J.; PIEPER, L. Randomized, blinded, controlled clinical trial shows no benefit of homeopathic mastitis treatment in dairy cows. Journal of Dairy Science, v. 100, n. 6, p. 48574-4867, 2017. doi: $10.3168 /$ jds.2016-11805.

ENBERGS, H. Homeopathy. Compounds for the prevention of ovarian dysfunction. Milchpraxis, v. 36, p. 5-8, 1998.

FENTON, M.; KEARY, R.; MCAULIFFE, O.; ROSS, R. P.; O'MAHONY, J.; COFFEY, A. Bacteriophage-derived peptidase $\mathrm{CHAP}_{\mathrm{K}}$ eliminates and prevents staphylococcal biofilms. International Journal of Microbiology, v. 2013, e625341, p. 1-8, 2013. doi: 10.1155/2013/625341.

FONSECA, A. P.; ESTRELA, F. T.; MORAES, T. S.; CARNEIRO, L. J.; BASTOS, J. K.; SANTOS, R. A.; AMRÓSIO, S. R.; MARTINS, C. H. G.; VENEZIANI, R. C. S. In vitro antimicrobial activity of plant-derived diterpenes against bovine mastitis bacteria. Molecules, v. 18, n. 7, p. 78965-7872, 2013. doi: 10.3390/molecules 18077865 .

FREESE, E.; SHEU, C. W.; GALLIERS, E. Function of lipophilic acids as antimicrobial food additives. Nature, v. 241, n. 5388, p. $321-325$, 1973. doi: 10.1038/241321a0.
GARBE, S.; KLOCKE, P.; SPRANGER, J.; MERCK, C. C. Therapy of clinical mastitis by homeopathic medication. Reproduction in Domestic Animals, v. 35, n. 1, p. 17-18, 2000.

GIRAUDO, J. A.; CALZOLARI, H.; RAMPONE, H.; RAMPONE, A.; GIRAUDO, A. T.; BOGNI, C.; LARRIESTRA, A.; NAGEL, R. Field trials of a vaccine against bovine mastitis. 1. Evaluation in heifers. Journal of Dairy Science, v. 80 , n. 5, p. $845-853,1997$. doi: 10.3168/jds.S0022-0302(97)76006-5.

GLASSMAN, H. N. Surface active agents and their application in bacteriology. Bacteriological Reviews, v. 12, n. 2, p. 105-148, 1949.

GRUMMER, R. R.; SOCHA, M. T. Milk fatty acid composition and plasma energy metabolite concentrations in lactating cows fed medium-chain triglycerides. Journal of Dairy Science, v. 72, n. 8, p. 19962001, 1989. doi: 10.3168/jds.S0022-0302(89)79323-1.

HAFEZ, S. M.; ISMAEL, A. B.; MAHMOUD, M. B.; ELARABY, A. A. Development of new strategy for nonantibiotic therapy: bovine lactoferrin has a potent antimicrobial and immunmodulator effects. Advances in Infectious Diseases, v. 3, n. 3, p. 185-192, 2013. doi: 10.4236/aid.2013.33027.

HAHNEMANN, S. Organon der rationellen Heilkunde. v. 1. Arnold: Dresden, 1810.

HALASA, T.; HUIJPS, K.; OSTERAS, O.; HOGEVEEN, H. Economic effects of bovine mastitis and mastitis management: a review. Veterinary Quarterly, v. 29, n. 1, p. 18-31, 2007. doi: 10.1080/01652176.2007.9695224.

HEKTOEN, L. Investigations of the motivation underlying Norwegian dairy farmers' use of homeopathy. Veterinary Record, v. 155, n. 22, p. 701-707, 2004.

HENG, N. C.; WESCOMBE, P. A.; BURTON, J. P.; JACK, R. W.; TAGG, J. R. The diversity of bacteriocins in Grampositive bacteria. In: ECKEY, C. (Ed.) Bacteriocins ecology and evolution. Berlin: Springer, 2007.

HENRY, G. E.; MOMIN, R. A.; NAIR, M. G.; DEWITT, D. L. Antioxidant and cyclooxygenase activities of fatty acids found in food. Journal of Agricultural and Food Chemistry, v. 50, n. 8, p. 2231-2234, 2002. doi: 10.1021/jf0114381. 
HOGAN, J. S.; PANKEY, J. W.; DUTHIE, A. H. Growth inhibition of mastitis pathogens by long-chain fatty acids. Journal of Dairy Science, v. 70, n. 5, p. 927-934, 1987. doi: 10.3168/jds.S0022-0302(87)80096-6.

HOGAN, J. S.; SMITH, K. L.; TODHUNTER, D. A.; SCHOENBERGER, P. S. Field trial to determine efficacy of an Escherichia coli J5 mastitis vaccine. Journal of Dairy Science, v. 75, n. 1, p. 78-84, 1992. doi: 10.3168/jds.S00220302(92)77741-8.

ISAACS, C. E.; LITOV, R. E.; THORMAR, H. Antimicrobial activity of lipids added to human milk, infant formula, and bovine milk. Journal of Nutritional Biochemistry, v. 6, n. 7, p. 362-366, 1995.

JANEWAY, C. A.; TRAVERS, P.; WALPORT, M. Immunobiology: the immune system in health and disease. $5^{\text {th }}$ ed. New York: Garland Science, 2001.

JANSEN, J.; VAN DEN BORNE, B. H. P.; RENES, R. J.; VAN SCHAIK, G.; LAM, T. J. G. M.; LEEUWIS, C. Explaining mastitis incidence in Dutch dairy farming: the influence of farmers' attitudes and behaviour. Preventive Veterinary Medicine, v. 92, n. 3, 210-223, 2009. doi: 10.1016/j.prevetmed.2009.08.015.

KABARA, J. J. Fatty acids and derivatives as antimicrobial agenst. In: KABARA, J. J. (Ed.) The pharmacological effect of lipids. St. Louis, MO.: American Oil Chemists Society, 1978. p. 1-14.

KAZEMI, J.; AHMADI, M.; SAEI, H. D.; HESAMI, M. A. Antibacterial effect of silver nanoparticles along with protein synthesis-inhibiting antibiotcs on $S$. aureus isolated from cattle mastitis. Biological Journal of Microorganism, v. 2, n. 8, p. 15-22, 2014.

KWIATEK, M.; PARASION, S.; MIZAK, L.; GRYKO, R.; BAROSZCZE, M.; KOCIK, J. Characterization of a bacteriophage, isolated from a cow with mastitis, that is lytic against Staphylococcus aureus strains. Archives of Virology, v. 157, n. 2, p. 225-234, 2012. doi: 10.1007/s00705-011-1160-3.

LEE, J. W.; PAAPE, M. J.; ELSASSER, T. H.; ZHAO, X. Elevated milk soluble CD14 in bovine mammary glands challenged with Escherichia coli lipopolysaccharide. Journal of Dairy Science, v. 86, n. 7, p. 2382-2389, 2003. doi: 10.3168/jds.S0022-0302(03)73832-6.
LEITNER, G.; PINCHASOV, Y.; MORAG, E.; SPANIER, Y.; JACOBY, S.; ELIAU, D.; PITCOVSKI, J. Immunotherapy of mastitis. Veterinary Immunology and Immunopathology, v. 153, n. 3-4, p. 209-216, 2013. doi: 10.1016/j.vetimm.2013.02.017.

LUBY, C. D.; MIDDLETON, J. R.; MA, J.; RINEHART, C. L.; BUCKLIN, S.; KOHLER, C.; TYLER, J. W. Characterization of the antibody isotype response in serum and milk of heifers vaccinated with Staphylococcus aureus bacterin (Lysigin ${ }^{\mathrm{m}}$ ). Journal of Dairy Research, v. 74, n. 2, p. 239-246, 2007. doi: $10.1017 /$ S0022029907002476.

MATHIE, R. T.; CLAUSEN, J. Veterinary homeopathy: Meta-analysis of randomised placebo-controlled trials. Homeopathy, v. 104, n. 1, p. 3-8, 2015 . doi: 10.1016/j.homp.2014.11.001.

MEHRZAD, J.; DUCHATEAU, L.; BURVENICH, C. Viability of milk neutrophils and severity of bovine coliform mastitis. Journal of Dairy Science, v. 87 , n. 12, p. 41504162, 2004. doi: 10.3168/jds.S0022-0302(04)73558-4.

MERCK, C. C.; SONNENWALD, B.; ROLLWAGE, H. Studies in the treatment of acute bovine mastitis with homeopathic drugs. Berliner Und Munchener Tierarztliche Wochenschrift, v. 102, p. 266-272, 1989.

MIDDLETON, J. R.; MA, J. N.; RINEHART, C. L.; TAYLOR, V. N.; LUBY, C. D.; STEEVENS, B. J. Efficacy of different Lysigin ${ }^{\mathrm{m}}$ formulations in the prevention of Staphylococcus aureus intramammary infection in dairy heifers. Journal of Dairy Research, v. 73, n. 1, p. 10-19, 2006. doi: 10.1017/S0022029905001354.

MONK, J. D.; BEUCHAT, L. R.; HATCOX, A. K. Inhibitory effects of sucrose monolaurate, alone and in combination with organic acids, on Listeria monocytogenes and $S$. aureus. Journal of Applied Bacteriology, v. 81, n. 1, p. 7-18, 1996.

NAIR, M. K. M.; JOY, J.; VASUDEVAN, P.; HINCKLEY, L.; HOAGLAND, T. A.; VENKITANARAYANAN, K. S. Antibacterial effect of caprylic acid and monocaprylin on major bacterial mastitis pathogens. Journal of Dairy Science, v. $88, \quad$ n. 10, p. $3488-3495,2005$. doi: 10.3168/jds.S0022-0302(05)73033-2.

NICKERSON, S. C.; OWENS, W. E.; TOMITA, G. M.; WIDEL, P. Vaccinating dairy heifers with a $S$. aureus 
bacterin reduces mastitis at calving. Large Animal Practice, v. 20, p. 16-28, 1999.

O'FLAHERTY, S.; COFFEY, A.; MEANY, W. J.; FITZGERALD, G. F.; ROSS, R. P. Inhibition bacteriophage K proliferation on Staphylococcus aureus raw bovine milk. Letter of Applied Microbiology, v. 41, n. 3, p. 274-279, 2005. doi: 10.1111/j.1472-765X.2005.01762.x.

PELLEGRINO, M.; GIRAUDO, J.; RASPANTI, C.; NAGEL, R.; ODIERNO, L.; PRIMO, V.; BOGNI, C. Experimental trial in heifers vaccinated with Staphylococcus aureus avirulent mutant against bovine mastitis. Veterinary Microbiology, v. 127, n. 1-2, p.186190, 2008. doi: 10.1016/j.vetmic.2007.07.028.

PÉREZ, M. M.; PRENAFETA, A.; VALLE, J.; PENADÉS, J.; ROTA, C.; SOLANO, C.; MARCO, J.; GRILLÓ, M. J.; LASA, I.; IRACHE, J. M.; MAIRA-LITRAN, T.; JIMÉNEZ-BARBERO, J.; COSTA, L.; PIER, G. B.; DE ANDRÉS, D.; AMORENA, B. Protection from Staphylococcus aureus mastitis associated with poly-Nacetyl $\beta-1,6$ glucosamine specific antibody production using biofilm-embedded bacteria. Vaccine, v. 27, n. 17, p. 2379-2386, 2009. doi: 10.1016/j.vaccine.2009.02.005.

PICCART, K.; VÁSQUEZ, A.; PIEPERS, S.; DE VLIEGHER, S.; OLOFSSON, T. C. Short communication: Lactic acid bacteria from the honeybee inhibit the in vitro growth of mastitis pathogens. Journal of Dairy Science, v. 99, n. 4, p. 2940-2944, 2016. doi: 10.3168/jds.2015-10208.

PIEPERS, S.; DE VLIEGHER, S. Oral supplementation of medium-chain fatty acids during the dry period supports the neutrophil viability of peripartum dairy cows. Journal of Dairy Research, v. 80, n. 3, p. 309-318, 2013. doi: $10.1017 /$ S0022029913000228.

PIEPERS, S.; PRENAFETA, A.; VERBEKE, J.; DE VISSCHER, A.; MARCH, R.; DE VLIEGHER, S. Immune response after an experimental intramammary challenge with killed Staphylococcus aureus in cows and heifers vaccinated and not vaccinated with Startvac, a polyvalent mastitis vaccine. Journal of Dairy Science, v. 100, n. 1, p. 769-782, 2017. doi: 10.3168/jds.2016-11269.

PRENAFETA, A.; MARCH, R.; FOIX, A.; CASALS, I.; COSTA, L. Study of the humoral immunological response after vaccination with a Staphylococcus aureus biofilmembedded bacterin in dairy cows: possible role of the exopolysaccharide specific antibody production in the protection from Staphylococcus aureus induced mastitis. Veterinary Immunology and Immunopathology, v. 134, n. 3-4, p. 208-217, 2010. doi: 10.1016/j.vetimm.2009.09.020.

PROJAN, S. J.; BROWN-SKROBOT, S.; SCHLIEVERT, P. M.; VANDENESCH, F.; NOVICK, R. P. Glycerol monolaurate inhibits the production of $\beta$-lactamase, toxic shock syndrome toxin-1, and other staphylococcal exoproteins by interfering with signal transduction. Journal of Bacteriology, v. 176, n. 14, 4204-4209, 1994.

RAINARD, P.; RIOLLET, C. Innate immunity of the bovine mammary gland. Veterinary Research, v. 37, n. 3, p. 369-400, 2006. doi: 10.1051/vetres:2006007.

RUEGG, P. L.; TABONE, T. J. The relationship between antibiotic residue violations and somatic cell counts in Wisconsin dairy herds. Journal of Dairy Science, v. 83, n. 12 , p. $2805-2809$, 2000. doi: 10.3168/jds.S00220302(00)75178-2.

RUZIN, A.; NOVICK, R. P. Glycerol monolaurate inhibits induction of vancomycin resistance in Enterococcus faecalis. Journal of Bacteriology, v. 180, n. 1, p. 182-185, 1998.

RYAN, M. P.; FLYNN, J.; HILL, C.; ROSS, R. P.; MEANEY, W. J. The natural food grade inhibitor, Lacticin 3147 , reduced the incidence of mastitis after experimental challenge with Streptococcus dysgalactiae in nonlactating dairy cows. Journal of Dairy Science, v. 82, n. 10, p. 2108 2131, 1999. doi: 10.3168/jds.S0022-0302(99)75453-6.

SCHUKKEN, Y. H.; BRONZO, V.; LOCATELLI, C.; POLLERA, C.; ROTA, N.; CASULA, A.; TESTA, F.; SCACCABAROZZI, L.; MARCH, R.; ZALDUENDO, D.; GUIX, R.; MORONI, P. Efficacy of vaccination on Staphylococcus aureus and coagulase-negative staphylococci intramammary infection dynamics in 2 dairy herds. Journal of Dairy Science, v. 97, n. 8, p. 5250-5264, 2014. doi: 10.3168/jds.2014-8008.

SCHUKKEN, Y. H.; GÜNTHER, J.; FITZPATRICK, J.; FONTAINE, M. C.; GOETZE, L.; HOLST, O.; LEIGH, J.; PETZL, W.; SCHUBERTH, H. J.; SIPKA, A.; SMITH, D. G.; QUESNELL, R.; WATTS, J.; YANCEY, R.; ZERBE, H.; ZADOKS, R. N.; SEYFERT, H. M.; MEMBERS OF THE PFIZER MASTITIS RESEARCH CONSORTIUM. Hostresponse patterns of intramammary infections in dairy cows. Veterinary Immunology and Immunopathology, v. 144, n. 3-4, p. 270-289, 2011. doi: 10.1016/j.vetimm.2011.08.022. 
SEARS, P. M.; SMITH, B. S.; STEWART, W. K.; GONZALEZ, R. N.; RUBINO, S. D.; GUSIK, S. A.; KULISEK, E. S.; PROJAN, S. J.; BLACKBURN, P. Evaluation of nisin-based germicidal formulation on teat skin of live cows. Journal of Dairy Science, v. 75, n. 11, p. 3185-3190, 1992. doi: 10.3168/jds.S0022-0302(92)78083-7.

SHAFER-WEAVER, K. A.; SORDILLO, L. M. Enhancing bactericidal activity of bovine lymphoid cells during the periparturient period. Journal of Dairy Science, v. 79, n. 8, p. 1347-1352, 1996. doi: 10.3168/jds.S0022-0302(96)76491-3.

SMITH, C. F. Criticisms of veterinary homeopathic practice and research. Australian Veterinary Journal, v. 80, n. 5, p. 264-266, 2002.

SORDILLO, L. M. Factors affecting mammary gland immunity and mastitis susceptibility. Livestock Production Science, v. 98, n. 1-2, p. 89-99, 2005. doi: 10.1016/j.livprodsci.2005.10.017.

SORDILLO, L. M.; AITKEN, S. L. Impact of oxidative stress on the health and immune function of dairy cattle. Veterinary Immunology and Immunopathology, v. 128, n. 1-3, p. 104109, 2009. doi: 10.1016/j.vetimm.2008.10.305.

STEVENS, M.; PIEPERS, S.; SUPRÉ, K.; DEWULF, J.; DE VLIEGHER, S. Quantification of antimicrobial consumption in adult cattle on dairy herds in Flanders, Belgium, and associations with udder health, milk quality, and production performance. Journal of Dairy Science, v. 99, n. 3, p. 2118-2130, 2016. doi: 10.3168/jds.2015-10199.

SUN, C. Q.; O'CONNOR, C. J.; ROBERTON, A. M. The antimicrobial properties of milkfat after partial hydrolysis by calf pregastric lipase. Chemico-Biological Interactions, v. 140, n. 2, p. 185-198, 2002. doi: 10.1016/S0009-2797(02)00016-9.

SUTRA, L.; MENDOLIA, C.; RAINARD, P.; POUTREL, B. Encapsulation of Staphylococcus aureus isolates from mastitic milk: Relationship between capsular polysaccharide types 5 and 8 colony morphology in serum-soft agar, clumping factor, teichoic acid and protein. Journal of Clinical Microbiology, v. 28, n. 3, p. 447-451, 1990.

TENHAGEN, B. A.; EDINGER, D.; BAUMGARTNER, B.; KALBE, P.; KLUNDER, G.; HEUWIESER, W. Efficacy of a herd-specific vaccine against $S$. aureus to prevent postpartum mastitis in dairy heifers. Journal of Veterinary Medicine A, v. 48, n. 10, p. 601-607, 2001.
THOMPSON-CRISPIE, K. A.; MIGLIOR, F.; MALLARD, B. A. Incidence rates of clinical mastitis among Canadian Holsteins classified as high, average, or low immune responders. Clinical and Vaccine Immunology, v. 20, n. 1, p. 106-112, 2013. doi: 10.1128/CVI.00494-12.

TREECE, J. M.; MORESE, G. E.; LLEVY, C. Lipid analyses of bovine teat canal keratin. Journal of Dairy Science, v. 49 , n. 10 , p. $240-1244$, 1966. doi: $10.3168 /$ jds.S00220302(66)88062-1.

TWOMEY, D. P.; WHEELOCK, A. I.; FLYNN, J.; MEANEY, W. J.; HILL, C.; ROSS, R. P. Protection against Staphylococcus aureus mastitis in dairy cows using a bismuth-based teat seal containing the bacteriocin, lacticin 3147. Journal of Dairy Science, v. 83, n. 9, p. 1981 1989, 2000. doi: 10.3168/jds.S0022-0302(00)75075-2.

VANDERHAEGHEN, W.; PIEPERS, S.; LEROY, F.; VAN COILLIE, E.; HAESEBROUCK, F.; DE VLIEGHER, S. Identification, typing, ecology, and epidemiology of coagulase-negative staphylococci associated with ruminants. Veterinary Journal, v. 203, n. 1, p. 44-51, 2015. doi: 10.1016/j.tvjl.2014.11.001.

VARSHNEY, J. P.; NARESH, R. Comparative efficacy of homeopathic and allopathic systems of medicine in the management of clinical mastitis of Indian dairy cows. Homeopathy, v. 94, n. 2, p. 81-85, 2005. doi: 10.1016/j.homp.2004.11.013.

VERSLEIJEN, M.; ROELOFS, H.; PREIJERS, F.; ROOS, D.; WANTEN, G. Parenteral lipids modulate leukocyte phenotypes in whole blood, depending on their fatty acid composition. Clinical Nutrition, v. 24, n. 5, p. 822-829, 2005. doi: 10.1016/j.clnu.2005.05.003.

VIEGAS, C. A.; SÁ-CORREIA, I. Activation of plasma membrane ATPase of Saccharomyces cerevisiae by octanoic acid. Journal of General Microbiology, v. 137, n. 3, p. 645-651, 1991. doi: 10.1099/00221287-137-3-645.

WANG, L. L.; JOHNSON, E. A. Inhibition of Listeria monocytogenes by fatty acids and monoglycerides. Applied and Environmental Microbiology, v. 58, n. 2, p. 624-629, 1992.

WANG, X. F.; ZHANG, S. L.; ZHU, L. Y.; XIE, S. Y.; DONG, Z.; WANY, Y.; ZHOU, W. Z. Enhancement of antibacterial activity of tilmicosin against $S$. aureus by solid lipid nanoparticles in vitro and in vivo. Veterinary Journal, v. 191, n. 1, p. 115-120, 2012. doi: 10.1016/j.tvjl.2010.11.019. 
WARTH, A. D. Transport of benzoic and propanoic acids by Zygosaccharomyces bailli. Journal of General Microbiology, v. 135, p. 1383-1390, 1989.

WERNER, C.; SOBIRAJ, A.; SUNDRUM, A. Efficacy of homeopathic and antibiotic treatment strategies in cases of mild and moderate bovine clinical mastitis. Journal of Dairy Research, v. 77, n. 4, p. 460-467, 2010. doi: $10.1017 /$ S0022029910000543.

WILSON, D. J.; GRÖHN, Y. T.; BENNETT, G. J.; GONZÁLEZ, R. N.; SCHUKKEN, Y. H.; SPATZ J. Comparison of J5 vaccinates and controls for incidence, etiologic agent, clinical severity, and survival in the herd following naturally occurring cases of clinical mastitis. Journal of Dairy Science, v. 90, n. 9, p. 4282-4288, 2007a. doi: 10.3168/jds.2007-0160.

WILSON, D. J.; GRÖHN, Y. T.; BENNETT, G. J.; GONZÁLEZ, R. N.; SCHUKKEN, Y. H.; SPATZ, J. Milk production change following clinical mastitis and reproductive performance compared among J5 vaccinated and control dairy cattle. Journal of Dairy Science, v. 91, n. 10, p. 3869-3879, 2008. doi: 10.3168/jds.2008-1405.

WILSON, D. J.; MALLARD, B. A.; BURTON, J. L.; SCHUKKEN, Y. H.; GRÖHN, Y. T. x Milk and serum J5specific antibody responses, milk production change, and clinical effects following intramammary E. coli challenge for J5 vaccinate and control cows. Clinical and Vaccine Immunology, v. 14, n. 6, p. 693-699, 2007b. doi: 10.1128/CVI.00104-07.

WILSON, D. J.; MALLARD, B. A.; BURTON, J. L.; SCHUKKEN, Y. H.; GRÖHN, Y. T. Association of Escherichia coli J5-specific serum antibody responses with clinical mastitis outcome for J5 vaccinate and control dairy cattle. Clinical and Vaccine Immunology, v. 16, n. 2, p. 209-217, 2009. doi: 10.1128/CVI.00324-08.

XUEFENG, Y.; WUQING, O.; JIANGCAI, S.; XIANGHUI, L. Post-antibiotic effect of amoxicillin nanoparticles against main pathogenic bacteria of bovine mastitis in vitro. Journal of Nothwest Sci-Tech University of Agriculture and Forestry, v. 37, n. 6, p. 1-6, 2009. 